\title{
Investigation of the dispersion processes of composite colloidal capillary-porous materials
}

\author{
Zh.O. Petrova (0000-0001-7385-8495), V.M. Vyshnievskyi (0000-0002-2424-8102), \\ Yu.P. Novikova (0000-0002-6705-1000), A.I. Petrov (0000-0003-4851-3115) \\ Institute of Engineering Thermophysics of NAS of Ukraine, str. Bulakhovskogo, 2, Bldg. 2, Kyiv, 03164, Ukraine \\ Tel.: +380444249639, +380444249644 \\ E-mail: bergelzhanna@ukr.net
}

Article info: received 20.11.2019, revised 29.11.2019, accepted 13.12.2019

Petrova, Zh.O., Vyshnievskyi, V.M., Novikova, Yu.P., Petrov, A.I. (2019) Investigation of the dispersion processes of composite colloidal capillary-porous materials 4(45), doi: 10.26909/csl.4.2019.3

The technology of drying colloidal capillary-porous materials to a final humidity of $6-8 \%$, developed at the Institute of Technical Thermophysics of the NAS of Ukraine, allowed to obtain a brittle state, in which it is possible to grind this product to small particles.

The most suitable for industrial grinding of the dried composite colloidal capillary-porous materials is the impact method, because when wiping and crushing the material has accumulated, stuck to the working surface.

Powders are characterized by one pronounced maximum corresponding to the particle size of the powder of 0,16 $\mathrm{mm}$. As the rotation speed of the shredder rotor changes, the particle size distribution of $0,16 \mathrm{~mm}$ increases by reducing the larger particles.

The amount of powder thus obtained is directly proportional to the speed of rotation of the rotor. The study of the dispersion and classification of functional powders showed that all powders have the largest particle size of $0,16 \mathrm{~mm}$. The maximum yield of this fraction is $70 \%$ and the lowest is $40 \%$.

The structural-mechanical characteristics of powders from composite colloidal capillary-porous materials were investigated for the first time. Characteristics of different fractions were determined by such parameters as bulk density, vibration density, angle of natural slope, speed of material flow through the funnel and others.

Studies to determine the structural and mechanical properties of functional powders have shown that they can be attributed to more bulk powders, as opposed to highly bound monopowders. Creating compositions improves their structural and mechanical properties.

Key words: composite colloidal capillary-porous materials, grinding.

\section{Дослідження процесів диспергування композиційних колоїдних капілярно-пористих матеріалів}

\author{
Ж.О. Петрова, В.М. Вишнєвський, Ю.П. Новікова, А.І. Петров \\ Інститут технічної теплофізики НАН Украӥни, Київ, Україна
}

Розроблена в Інституті технічної теплофізики НАН України технологія сушіння колоїдних капілярно-пористих матеріалів до кінцевої вологості 6 - 8 \%, дозволила отримати крихкий стан, при якому можна подрібнити цей продукт до дрібних частинок.

Найбільш придатним для промислового подрібнення висушених композиційних колоїдних капілярно-пористих матеріалів $є$ ударний спосіб, тому що при протиранні та розчавлювані матеріал комкувався і прилипав до робочої поверхні.

\section{Ветуп}

Враховуючи загальну тенденцію енергоспоживання, яка веде до збільшення кількості спожитої енергії в усьому світі, вартість цієї енергії безперервно підвищується та зростає іï дефіцит. Тому гостро стоять проблеми створення та широко масштабного впровадження сучасних енергоефективних 
теплотехнологій, які забезпечують скорочення споживання енергоносіїв, в тому числі в процесах диспергування.

Мета роботи полягає у проведенні дослідження процесів диспергування композиційної сировини із співвідношенням компонентів 2:1 для визначення оптимальних режимів сушіння.

\section{Матеріали та методи дослідження}

Дослідження процесів диспергування сухого композиційного рослинного матеріалу проведені на дезінтеграторі ДЕ ЗІ-1М.

При побудові диференційних кривих розподілення маси на вісі абсцис відкладені значення діаметрів часток - від найменшого $\delta_{\text {min }}$ до найбільшого $\delta_{\max }$, а по вісі ординат - функція розподілення маси:

$$
F(\delta)=\frac{\Delta m}{M_{Y} \cdot \Delta \delta},
$$

де $M_{\Psi}$ - загальна маса всіх часток, $г ; \Delta m$ - маса частинок в інтервалі розмірів від $\delta$ до $\Delta \delta, \Gamma$.

Порошки, що отримані внаслідок диспергування сухих композиційних колоїдних капілярно-пористих матеріалів складаються з суміші часток різного розміру. Ці суміші розділяли на різні фракції в залежності до вимог використання [1 - 4].

Аналіз дисперсності композиційного порошку наведено на рисунку 1 .

Диференціальні криві розподілу маси сухого композиційного порошку в залежності від швидко- сті обертання ротору дезінтегратору показали, що вони мають два максимальні значення (рис. 1).

Максимальні значення розподілу маси знаходяться при дисперсності порошку 0,16 та 0,4 мм. Найвище диференційне розподілення маси порошку суміші спостерігається при розмірах порошку 0,16 мм.

\section{Результати та їх обговорення}

На інтегральних кривих розподілу маси порошку показаний вплив швидкості обертання ротору дезінтегратора та часу просіювання на фракційний склад порошку. Інтегральні криві розподілу маси порошку засвідчують, що з підвищенням швидкості обертання ротору дезінтегратора та часу просіювання підвищується вміст високодисперсної фракції. Наприклад, при швидкості обертання ротору дезінтегратору 30 м/с вміст високодисперсної фракції 3 часом просіювання 5 хв. становить 27,6 \%, а при швидкості обертання 80 м/с з тим же часом - вихід порошку збільшується в 2,52 рази (рис. 2).

Збільшення тривалості просіювання порошку на ситах менше 0,25 мм показали, що вихід високодисперсної фракції збільшується. Але при швидкості обертання 80 м/с час просіювання порошку з необхідністю зменшення енергетичних витрат можна прийняти 3 хв., тому що вихід високодисперсного порошку від збільшення часу до 7 хв. не перевищує $1 \%$ (рис. 3).

3 зменшенням швидкості обертання ротору час просіювання бажано збільшувати до 5 хв. (70 м/с)

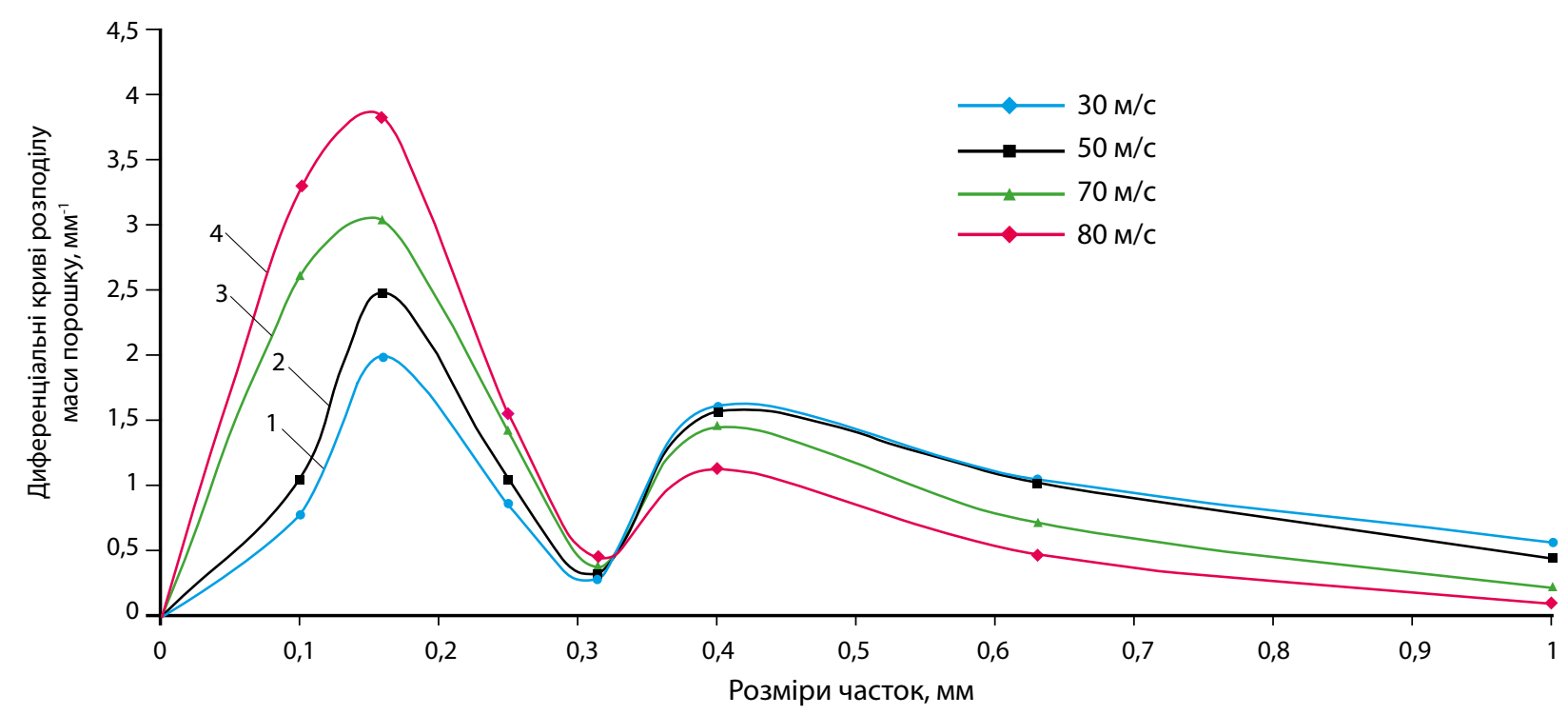

Рис. 1. Диференціальні криві розподілення маси порошку з композиційних колоїдних капілярно-пористих матеріалів суміші від розміру часток при швидкості обертання роторів дезінтегратора: $1-30 \mathrm{M} / \mathrm{c}$, $2-50$ м/с, $3-70$ м/с, $4-80$ м/с та часу просіювання 5 хв., співвідношення компонентів сировини 2:1 


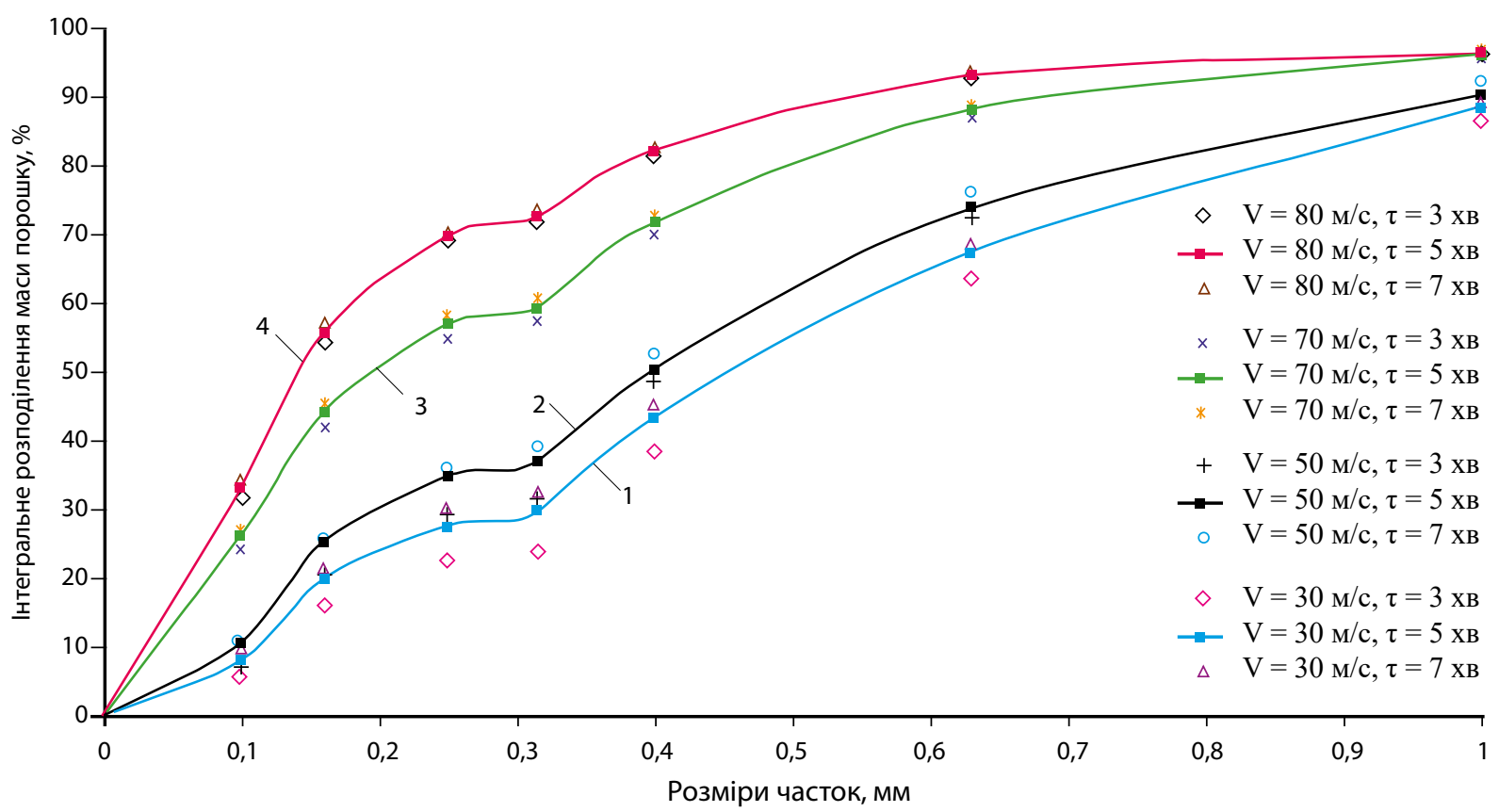

Рис. 2. Інтегральні криві розподілення маси порошку з композиційних колоїдних капілярно-пористих матеріалів суміші від розміру часток при швидкості обертання роторів дезінтегратора: $1-30 \mathrm{~m} / \mathrm{c}, 2-50 \mathrm{~m} / \mathrm{c}, 3-70 \mathrm{~m} / \mathrm{c}, 4-80 \mathrm{~m} / \mathrm{c} 3$ різним часом просіювання

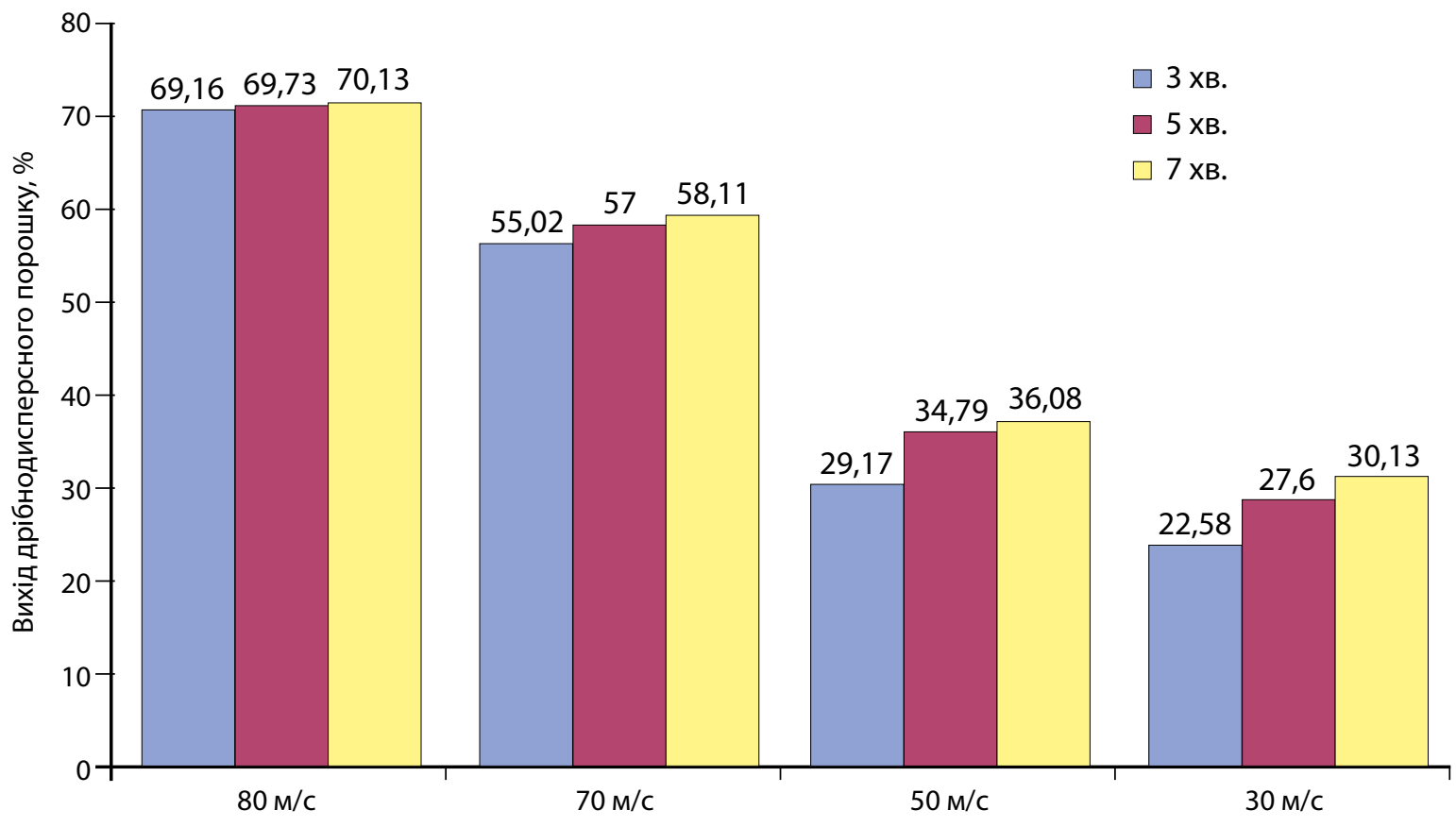

Швидкість обертання ротору дезінтегратора, м/с

Рис. 3. Вихід високодисперсної фракції композиційних колоїдних капілярно-пористих матеріалів від швидкості обертання ротору дезінтегратору з різним часом просіювання 
та до 7 хв. (50 та 30 м/с). Тому для порівняння інтегральних та диференціальних кривих розподілу маси порошків нами був взятий середній час просіювання 5 хв., який більш орієнтований на отримання високодисперсного порошку з великою швидкістю обертання ротору -70 та $80 \mathrm{~m} / \mathrm{c}$ [5].

Поведінка порошків в технологічних процесах визначається їх властивістю створювати опір зміни об'єму, форми, порушення цілісності.

Структурно-механічні властивості порошкоподібних матеріалів визначені за допомогою методів оцінки плинності та міцних характеристик порошків.

Насипна щільність порошку залежить від умов засипки. 3 збільшенням висоти падіння порошку щільність збільшується, а при збільшенні швидкості насипання, зменшується. Насипну щільність порошку $\rho_{H}$ визначали шляхом засипання порошку через воронку в спеціальний мірний металевий стакан із внутрішнім діаметром 45 мм за ГОСТ 11035.1 - 93.

Визначення вібраційної ущільненості порошку знаходилась від дії на ємність 3 порошком вібрації 3 амплітудою $\mathrm{A}=5$ мм і частотою $n=180 \mathrm{xB}^{-1}$ протягом 3 хв.

Значення насипної щільності порошків не дозволяють порівнювати матеріали, які відрізняються за формою та щільністю часток. Таке порівняння можливе на основі співвідношення, наприклад при вільному засипанні $\rho_{\Pi \text { }}$ та після струшування $\rho_{y}$.

Ущільненість У порошків визначається за формулою

$$
y=\frac{\rho_{y}-\rho_{H}}{\rho_{y}} \cdot 100, \%
$$

де $\rho_{y}-$ об'ємна щільність порошку після ущільнення, кГ/ $\mathrm{M}^{3}$.

При оцінці текучості порошків користуються коефіцієнтом ущільнення порошку. Збільшення сил аутогезії і тертя викликає зростання величини $K_{y}$

$$
K_{y}=\frac{\rho_{y}}{\rho_{H}} .
$$

Кутом природного укосу називають кут між горизонталлю і утворюючою купкою порошкоподібного матеріалу.

Кут природного укосу (динамічний кут укосу) використовують для визначення нахилу жолобів і стінок воронок, місткість транспортних засобів та сховищ. Кут природного укосу одночасно пов'язаний з аутогезією, внутрішнім тертям та щільністю часток порошку. Він дає безпосереднє уявлення про текучість порошку в стані вільного насипання. Діапазон зміни кута природного укосу коливається від $25-35^{\circ}$ для гарно сипких порошків і до $60-70^{\circ}$ i більше для зв'язаних [6].
Для визначення куту природного укосу використовувався пристрій, який складався з вертикальної стійки з закріпленим на ній рухомим конусом та піддоном з міліметровим папером, на який висипається порошок [7].

Кут природного укосу розраховується за наступною формулою

$$
\alpha=\operatorname{arctg} \frac{H}{d},
$$

де $H$ - висота конусу, мм; $d$ - діаметр основи конусу, мм.

Кут обрушення (статичний кут укосу) характеризує положення поверхні укосу, створений внаслідок сповзання частини порошкоподібного тіла. Кут обрушення завжди більше кута природного укосу. Кут обрушення за фізичним змістом більш наближений до кута внутрішнього тертя, так як утворення укосу відбувається в наслідок зсуву з руйнуванням структури порошку. Він виступає важливим параметром при проектуванні транспортних засобів та ємностей для зберігання порошку.

Коефіцієнт внутрішнього тертя $f$ визначається за формулою

$$
\operatorname{tg} \alpha=f
$$

Висота вільно стоячої вертикальної стінки $h_{c}-$ це комплексна характеристика. Вона відображає співвідношення між аутегізійною властивістю порошку, його внутрішнім тертям та щільністю, тобто характеризує умови руйнування та початок текучості порошку.

Міцності і реологічні властивості порошків зв'язують 3 їх властивістю утримувати вільно стоячу вертикальну стінку. 3 збільшенням аутогезійної властивості і внутрішнього тертя порошкоподібний матеріал стає міцнішим, достатнього для того, щоб протистояти руйнуванню під дією власної ваги. Чим вище міцність і менше щільність порошків, тим більше висота вільно стоячої вертикальної стінки.

Визначення тертя в індивідуальних контактах між частками дозволяє глибоко проаналізувати закономірності текучості порошків і оцінити фракційні властивості окремих елементів, їх форму та шершавість поверхні. Прямі вимірювання сили тертя між окремими частками, тобто міцності контактів на зсув, зробити складно, тому застосовують непрямі вимірювання.

Початковий опір здвигу визначається за формулою

$$
\tau_{0}=\frac{h_{c} \cdot \rho_{H}}{4},
$$

де $h_{c}$ - висота вільно стоячій вертикальній стінки, м. 
Таблиця 1.

Структурно-механічні характеристики композиційних колоїдних капілярно-пористих матеріалів, співвідношення рослинних компонентів 2:1

\begin{tabular}{|c|c|c|c|c|c|c|c|c|c|}
\hline \multirow[b]{2}{*}{ № } & \multirow[b]{2}{*}{ Назва характеристик } & \multicolumn{8}{|c|}{ Розміри частинок порошку, мм } \\
\hline & & $>0,1$ & $\begin{array}{l}0,1- \\
0,16\end{array}$ & $\begin{array}{c}0,16- \\
0,25\end{array}$ & $\begin{array}{l}0,25- \\
0,315\end{array}$ & $\begin{array}{c}0,315- \\
0,4\end{array}$ & $\begin{array}{l}0,4- \\
0,63\end{array}$ & $0,63-1$ & $<1$ \\
\hline 1. & Щільність, кг/м³ & 380 & 400 & 461 & 624 & 736 & 770 & 836 & 911 \\
\hline 2. & Вібраційна щільність, кг/м³ & 464 & 480 & 540 & 718 & 839 & 862 & 928 & 1002 \\
\hline 3. & Ущільненість, \% & 18,1 & 16,67 & 14,62 & 13,1 & 12,27 & 10,67 & 9,7 & 9,08 \\
\hline 4. & Коефіцієнт ущільнення & 1,22 & 1,2 & 1,17 & 1,15 & 1,14 & 1,12 & 1,11 & 1,1 \\
\hline 5. & Кут природного укосу, град. & 31,60 & 29,98 & 28,88 & 25,64 & 29,53 & 30,96 & 32,34 & 33,70 \\
\hline 6. & Кут обрушення, град. & 94 & 96 & 105 & 108 & 112 & 120 & 135 & 130 \\
\hline 7. & Коефіцієнт внутр. тертя & 1,12 & 1 & 0,84 & 0,76 & 0,68 & 0,6 & 0,54 & 0,48 \\
\hline 8. & $\begin{array}{c}\text { Висота вільно стоячої } \\
\text { вертикальної стінки, мм }\end{array}$ & 56 & 50 & 42 & 38 & 34 & 30 & 27 & 24 \\
\hline 9. & Початковий опір зсуву, Н/м² & 53,20 & 50 & 48,41 & 59,28 & 62,56 & 57,75 & 56,43 & 54,66 \\
\hline 10. & $\begin{array}{c}\text { Швидкість текучості } \\
\text { матеріалу через лійку } 12 \text { мм, г/с }\end{array}$ & 1,5 & 2,02 & 5,78 & 10,5 & 13,08 & 14,40 & 13,64 & 11,56 \\
\hline 11. & $\begin{array}{c}\text { Максимальний діаметр } \\
\text { вільноутворюючого отвору, мм }\end{array}$ & 97,77 & 85,35 & 69 & 61,47 & 53,11 & 45,43 & 39,82 & 34,39 \\
\hline
\end{tabular}

Для характеристики текучості порошків (сипучість) також використовується поняття швидкості витікання крізь воронку. Швидкість витікання пов'язано з умовами руху маси порошку в воронці до випускного отвору. Вона відбувається без порушення суцільності порошку за схемою пластичного потоку.

\section{Висновки}

Структурно-механічні характеристики порошків 3 композиційних колоїдних капілярно-пористих сумішей досліджувались вперше. Характеристики різних фракцій визначали за такими показниками як насипна щільність, вібраційна щільність, кут природного укосу, швидкість текучості матеріалу через лійку та інші.

Проведені дослідження з визначення структурно-механічних властивостей функціональних порошків показали, що їх можна віднести до більш сипучих порошків, на відміну від монопорошків, які $\epsilon$ дуже зв'язані. Створення композицій покращує їх структурно-механічні властивості.

\section{References}

1. Снежкин, Ю.Ф., Боряк, Л.А. Исследование процессов диспергирования сухих растительных материалов. Промышленная теплотехника. - 1982. - №4. - C. $43-45$.
2. Снежкин, Ю.Ф., Боряк, Л.А., Акинфиева, Л.Л., Демченко, В.В. Влияние параметров диспергирования и сепарации на дисперсный состав пищевых порошков из растительного сырья. Пищевая промышленность. - 1985. - № 11. - С. 33 - 34.

3. Бауман, B.A. Механическое оборудование предприятий строительных материалов, изделий и конструкций. В.А. Бауман. - М.: Машиностроение. 1981. $-332 \mathrm{c}$.

4. Боровський, В.Р. Изучение условий дробления и хранения порошков из яблок и яблочных выжимок. Промышленная теплотехника. - 1982. - № 5. C. $43-45$.

5. Петрова, Ж.О., Пазюк, В.М., Перепеличний, О.В. Дослідження процесу подрібнення та класифікації функціональної пребіотичної сировини. Збірник наукових статей «XVI Міжнародної науково-практичної конференції «Вдосконалення процесів і обладнання харчових і хімічних виробництв» Одеської національної академії харчових технологій. Мін. Освіти і науки України. - Одеса. $-2016$.

6. Зимон, А.Д. Аутогезия сипучих материалов. Зимон А.Д., Андрианов Е.И. - М. Металургія. - 1977. $-287 \mathrm{c}$.

7. Андрианов, Е.И. Методы определения структурно-механических характеристик порошкообразных материалов. - М.: Химия. - 1982. - 256 с. 